\title{
Increased Productivity towards the Success of Nothopanax Scutellarium in Case Of Hepatoprotector and Nefroprotector
}

\author{
Sri Wahyuni Nasution \\ Faculty of Medicine, Universitas Prima Indonesia \\ sriwahyuni_nst88@yahoo.com
}

\begin{abstract}
This study aims to determine the concentration of bowl leaf extract (Nothopanax scutellarium) which is effective in protecting impaired liver and kidney function. Liver damage can cause metabolic disorders in the body, which will lead to homeostatic disorders. Acute renal failure is a clinical problem, occurring frequently and characterized by a relatively sudden decline in renal function. This research is qualitative experimental research using a male rat (Rattus norvegicus) which is healthy and has normal activity, with a bodyweight of $200 \mathrm{~g}$. Male rats were adapted to be kept in cages for 7 days. Adaptation needed to be done to avoid the risk of stress in mice which could affect blood serum content. During the adaptation period, male rats are only given standard food and have not been given any treatment. At the end of the adaptation period, serum analysis was carried out in the five treatment groups. The results of the data obtained from this study were analyzed using the Oneway-Anova test.
\end{abstract}

Keywords

ethanol extract of mangkok leaves, increased productivity, kidney function

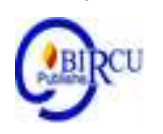

\section{Introduction}

Every health problem, generally caused by three factors that arise simultaneously, that are (1) the existence of other germs or disruptors,(2) the existence of an environment that allows the development of germs, and (3) the behavior of community not care about germs and the environment. Health and illness are largely determined by the human behavior. The behavior change problem is related to the effort of Health Promotion. Health Promotion is regulated in the Ministry of Health Regulation No. 1114 / Menkes / SK / VII / 2005 about Guidelines for Implementing Health Promotion in the Regions. Health Promotion is an effort to improve the abilityof the community through learning from, by, for and with the community, so that they can help themselves, and develop activities that are community-based, in accordance with local socio-cultural conditions and supported by public health-minded policies (Maswita, 2020).

The liver is one of the organs that have the potential to experience damage caused by various things, one of which is therapeutic chemicals because of its function in the metabolic process and detoxification of chemicals that will enter the body (Christine, 2017). Liver damage can cause metabolic disorders in the body so that it will cause homeostatic disorders ( $\mathrm{Lu}, 2010)$.

In Indonesia, one of the big problems is chronic hepatitis. Chronic hepatitis develops into a progressive form of liver cirrhosis which eventually becomes liver cancer which occurs in 20-30\% of cases (Syafitri, 2019).

The kidneys have specific functions including maintaining $\mathrm{H} 2 \mathrm{O}$ balance in the body, removing many foreign compounds, for example, drugs, pesticides, and non-nutritive exogenous substances that enter the body, helping to maintain the body's proper acid-base balance by adjusting $\mathrm{H}+$ expenditure (Sherwood, 2013 ). 
Acute renal failure is a clinical problem, occurring frequently and characterized by a relatively sudden decline in renal function. The prevalence of kidney failure or now known as CKD in Indonesia occurs in patients aged 15 years and over who were recorded based on the number of cases diagnosed by doctors of $0.2 \%$. The prevalence of chronic renal failure increases with age, increases rapidly at the age of 25-44 years $(0.3 \%)$ and the age of 45-54 years $(0.4 \%)$, age 55-74 years $(0.5 \%)$, and the incidence of the highest is at the age of more than 75 years $(0.6 \%)$ (RISKESDAS, 2013).

One of the drugs that can have hepatotoxic effects is paracetamol. Taking more doses of paracetamol will cause liver and kidney damage (Noer, 2017). Traditional medicine has been widely used in society, especially in the lower middle class. Traditional medicine is a mixture of natural ingredients derived from plants, animals, minerals, and so on. In Indonesia, we often encounter bowl leaf plants, this plant we often encounter in a plant (Qurota, 2017). The leaves of the bowl itself have properties in healing wounds, accelerating hair growth, and so on (Qurota, 2017). Bowl leaves have chemical compounds of flavonoids, saponins, tannins (Galuh, 2018). One of the mechanisms of liver and kidney damage is the buildup of free radicals. Flavonoids are compounds that capture free radicals (Noer, 2017).

Based on this, a study on the effect of Nothopanax scutellarium as a hepatoprotector and nephroprotector in Wistar rats (Rattus Norvegicus) induced by paracetamol was conducted to see the effect of bowl leaf extract (Nothopanax scutellarium) in protecting liver and kidney function until it was closer to normal through observation. SGPT enzymes (Serum Glutamic pyruvic Transaminase), SGOT (Serum Glutamic Oxalo Transaminase) Ureum, and Creatinine.

\section{Research Methods}

\subsection{Method of Research}

This research is experimental, namely research that describes or describes a situation in a phenomenon that has never been done before. With the development of bowl (Nothopanax scutellarium) leaf extract samples induced in Wistar rats (Rattus norvegicus). Then the hepatoprotection and nephroprotective tests were carried out to see the effect of hepatic and nephrondefense in Wistar rats (Rattus norvegicus) even though they had been induced by a toxic dose of paracetamol. Statistical data processing methods used statistical tests using SPSS software and statistical analysis was performed using one way ANOVA test.

\subsection{Collecting Data}

The method of collecting data includes the following steps:

a. Sample Preparation

The samples of leaves Nothopanax scutellarium were taken from the city of Medan, North Sumatra Province. Leaves taken are young, fresh, and not moldy. The collection is done in the morning.

b. Sample Processing

Samples that have been obtained are sorted wet, washed, then the leaves are dried by aerating until the leaves are dry. Furthermore, the leaves are cut into pieces and then pollinated and ready to be extracted.

c. Selection and Preparation of Experimental Animals

The experimental animals used were male rats (Rattus norvegicus) which were healthy and had normal activities, weighing $200 \mathrm{~g}$. Male rats were adapted to be kept in 
cages for 7 days. Adaptation needed to be done to avoid the risk of stress in mice which could affect blood serum content. During the adaptation period, male rats are only given standard food and have not been given any treatment. At the end of the adaptation period, serum analysis was carried out in the five treatment groups. This is done to determine the normal state of ALT activity from 17.5 to $30.2 \mathrm{U} / \mathrm{L}$.

d. Division of Experimental Animals

Wistar rats (Rattus norvegicus), as many as 36 tails, with a bodyweight of 200 grams. The tested animals were divided into 5 groups, each group consisting of 6 rats using the Federation formula.

- Group, I was a negative control group that was induced by Aquadest for 14 days.

- Group III rats were given Curcuma at a dose of $400 \mathrm{mg} / \mathrm{kg}$ (orally) starting on day 4, then given Paracetamol on days 13 and 14.

- Group III was the group that was induced by $100 \mathrm{mg} / 200 \mathrm{~g} \mathrm{BW}$ of bowl leaf extract (Nothopanax scutellarium) for 12 days, then the 13th day to the 14th day, induced by paracetamol $250 \mathrm{mg} / 200 \mathrm{grBB}$ rats.

- Group IV was the group induced by leaf bowl (Nothopanax scutellarium) as much as $300 / 200 \mathrm{~g}$ BW of rats for 12 days then day 13 to day 14 were induced by paracetamol $250 \mathrm{mg} / 200 \mathrm{grBB}$ of rats.

- Group V was the group induced by leaf bowl (Nothopanax scutellarium) as much as $600 \mathrm{mg} / 200 \mathrm{~g} \mathrm{BW}$ of rats for 12 days then day 13 to day 14 were induced by paracetamol $250 \mathrm{mg} / 200 \mathrm{~g} \mathrm{BW}$ of rats.

- Group V was the group that was induced by Aquadest drug for 12 days, then the 13th to 14th day of the induction of paracetamol $250 \mathrm{mg} / 200 \mathrm{grBB}$ rats.

e. Rat Blood Sampling

Blood samples were taken from the mice which were taken intravenously in the tail and then put into the Eppendorf tube.

f. processing of rat blood samples

The blood that has been obtained is then centrifuged at $3000 \mathrm{rpm}$ for 5 minutes to separate the plasma and serum

\section{Results and Discussion}

\subsection{Examination}

In this study, an examination of the kidney and liver function of male white rats was carried out. Renal function examination was characterized by the value of serum creatinine and urea from the blood of mice that had been treated with $0.5 \% \mathrm{Na}-\mathrm{CMC}$ suspension (group I), induction of doxorubicin at a dose of $15 \mathrm{mg} / \mathrm{Kg} \mathrm{BW}$ (group II), induction of doxorubicin at a dose of $15 \mathrm{mg} / \mathrm{Kg}$. BW $+100 \mathrm{mg} / \mathrm{kg}$ BW EEDM (group III), induction of doxorubicin dose $15 \mathrm{mg} / \mathrm{Kg} \mathrm{BW}+300 \mathrm{mg} / \mathrm{kg} \mathrm{BW}$ EEDM (group IV), induction of doxorubicin dose $15 \mathrm{mg} / \mathrm{Kg} \mathrm{BW}+600 \mathrm{mg} / \mathrm{kg} \mathrm{BW}$ EEDM (group V), and doxorubicin at a dose of $15 \mathrm{mg} / \mathrm{kg}+7.2 \mathrm{mg}$ super bio curcumin (group VI). Examination of serum creatinine and urea was carried out in the Medan health district laboratory.

\subsection{Serum Creatinine and Urea Levels}

This study was conducted to determine the effect of EEDM administration as a nephroprotective by measuring serum creatinine and urea levels. EEDM is given in several doses to determine the ability of EEDM to neutralize kidney damage. A decrease in serum creatinine levels and serum urea levels is a sign of acute renal failure (Kurniandari, et al., 2015). 
The administration of doxorubicin $15 \mathrm{mg} / \mathrm{kg} \mathrm{BW}$ to rats is intended as a toxic substance that will trigger kidney damage (Efendi, et al., 2016). Doxorubicin will cause a destructive effect on kidney cells (nephrotoxic) due to an increase in Reactive Oxygen Species (ROS). Proximal tubular cells, endothelial, basement membrane, mesangial cells, glomerular visceral cells will experience damage. Damage to these cells triggers the formation of debris or dead cells that can cause the release of macrophages. The release of macrophages causes the production of inflammatory cytokines, one of the most influential on kidney damage is TGF-beta 1, TGF-beta 1 triggers interstitial fibrosis which causes permanent kidney tissue damage, this is characterized by an increase in BUN and creatinine which proves a decrease in renal physiological function ((Heroweti J, et al., 2019).

Giving EEDM as a test material that has proven activity by increasing the dose in test animals. Even the highest dose provides activity as a nephroprotective which is not much different from super bio curcumin when seen from the decrease in serum creatinine levels. The decrease in serum creatinine levels along with the increasing dose of EEDM can be seen in Figure 1.

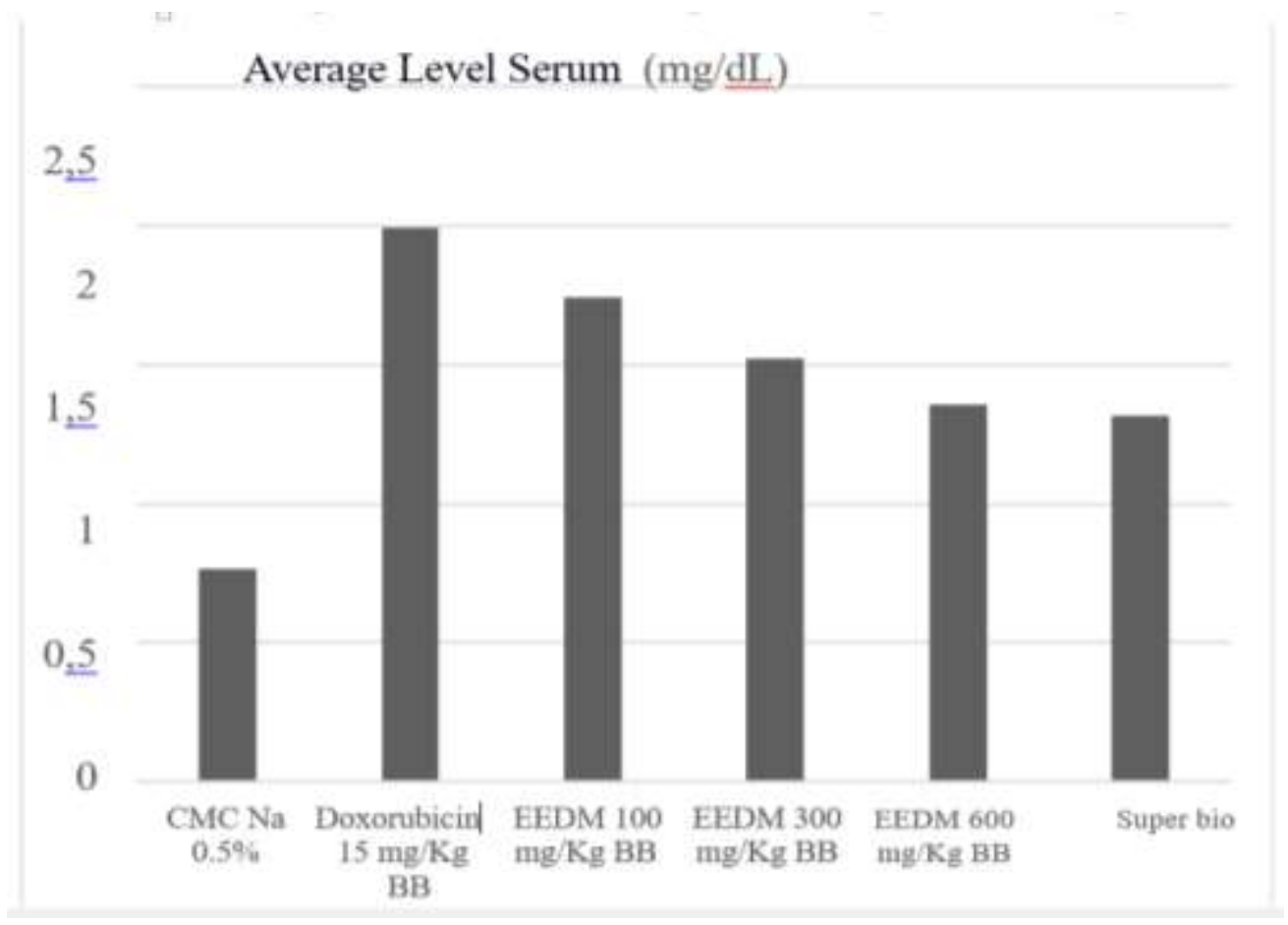

Figure 1. Average Level Serum

The EEDM treatment group at a dose of $300 \mathrm{mg} / \mathrm{kg}$ BW had a serum ALT value of $55.69 \pm 2.07 \mathrm{mg} / \mathrm{dl}$, the EEDM treatment group at a dose of $600 \mathrm{mg} / \mathrm{kg} \mathrm{BW}$ had a serum ALT value of $43.59 \pm 1.89 \mathrm{mg} / \mathrm{dl}$ and the treatment group super bio curcumin 7.2 $\mathrm{mg} / \mathrm{kg} \mathrm{BW}$ of $37.93 \pm 1.35 \mathrm{mg} / \mathrm{dl}$. Based on the table, it is known that the mean serum ALT in the largest treatment group is $70.18 \pm 1.22 \mathrm{mg} / \mathrm{dl}$ when induced by doxorubicin 15 $\mathrm{mg} / \mathrm{kg} \mathrm{BW}$ and EEDM at a dose of $100 \mathrm{mg} / \mathrm{kg} \mathrm{BW}$, while the mean serum ALT in the group The smallest treatment was $36.41 \pm 0.98$ in giving CMC-Na suspension without doxorubicin induction. Giving EEDM as a test material that has proven activity by increasing the dose in test animals. Even the highest dose provides activity as a hepatoprotection which is not much different from super bio-curcumin when seen from the decrease in ALT serum levels. The decrease in serum ALT levels along with the increasing dose of EEDM can be seen in Figure 2. 
Average Serum ALT $\pm \mathrm{SD}(\mathrm{U} / \mathrm{L})$

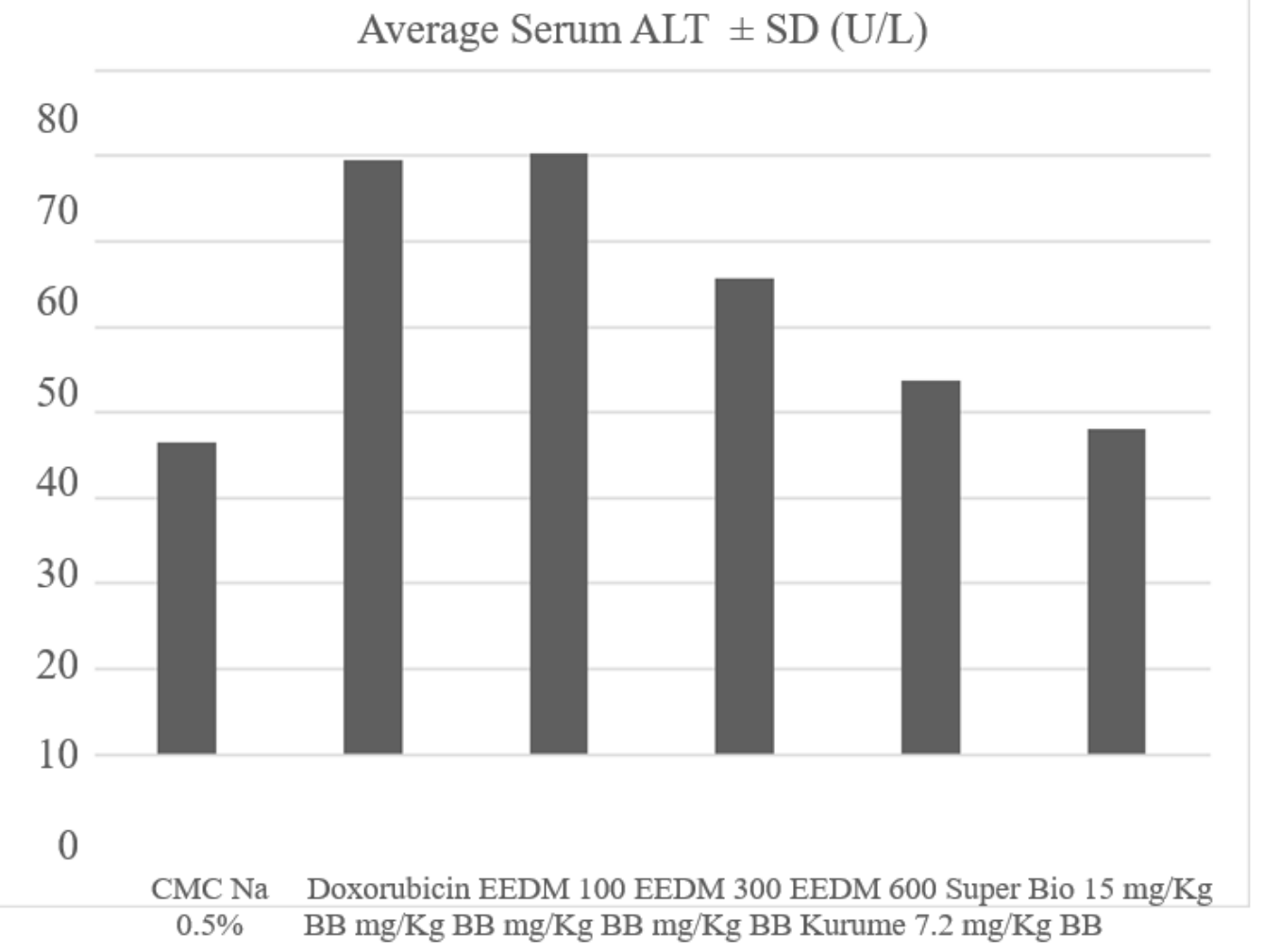

Figures 2. Average Serum ALT

Apart from serum ALT levels, serum AST levels are also a parameter of liver function. Based on Table 4.4, it is known that the average AST serum value for the normal group is still within the normal range of $35.8 \pm 0.91 \mathrm{mg} / \mathrm{dl}$. The doxorubicin induction group at a dose of $15 \mathrm{mg} / \mathrm{Kg} \mathrm{BW}$ had an average AST serum of $68.39 \pm 1.81 \mathrm{mg} / \mathrm{dl}$. The EEDM treatment group at a dose of $100 \mathrm{mg} / \mathrm{kg} \mathrm{BW}$ had the largest serum AST value of $69.79 \pm 0.54 \mathrm{mg} / \mathrm{dl}$. The EEDM treatment group at a dose of $300 \mathrm{mg} / \mathrm{kg} \mathrm{BW}$ had a serum AST value of $56.36 \pm 1.42 \mathrm{mg} / \mathrm{dl}$, the EEDM treatment group at a dose of $600 \mathrm{mg} / \mathrm{kg} \mathrm{BW}$ had a serum AST value of $43.39 \pm 3.00 \mathrm{mg} / \mathrm{dl}$ and the treatment group super bio curcumin $7.2 \mathrm{mg} / \mathrm{kg} \mathrm{BW}$ of $36.00 \pm 1.66 \mathrm{mg} / \mathrm{dl}$.

Giving EEDM with an increased dose can reduce the high ALT and AST values due to doxorubicin administration. This explains that EEDM has activity as a hepatoprotection. EEDM activity as a hepatoprotection cannot be separated from the content of secondary metabolites in the extract. One of the secondary metabolites that have strong activity as a hepatoprotection is flavonoids. Flavonoids are reported to be hepatoprotective because they have strong activity as antioxidants so that they can protect liver cells from attacking free radicals (Nurjihany K, et al, 2019).

\section{Conclusion}

The ethanol extract of leaves at a dose of $100 \mathrm{mg} / \mathrm{kg} \mathrm{BW}, 300 \mathrm{mg} / \mathrm{kg} \mathrm{BW}$, and 600 $\mathrm{mg} / \mathrm{kg} \mathrm{BW}$ have nephroprotective and hepatoprotective activity by reducing the value of creatinine levels, urea levels, ALT levels, and AST levels of doxorubicin-induced male white rats at a dose of $15 \mathrm{mg} / \mathrm{kg} \mathrm{BW}$. The effective dose of leaf ethanol extract as a neuroprotective and hepatoprotective is at a dose of $600 \mathrm{mg} / \mathrm{kg} \mathrm{BW}$. 
Increasing the dose of ethanol extract of leaves from doses of $100 \mathrm{mg} / \mathrm{kg} \mathrm{BW}, 300$ $\mathrm{mg} / \mathrm{kg} \mathrm{BW}$, and $600 \mathrm{mg} / \mathrm{kg} \mathrm{BW}$ showed an increase in nephroprotective and hepatoprotective activity.

\section{References}

Adiyati, P. N.(2011). Ragam Jenis Ektoparasit pada Hewan Coba Tikus Putih (Rattus norvegicus) Galur Sprague Dawley. Skripsi. Fakultas Kedokteran Hewan Institut Pertanian Bogor. Bogor.

Azis, A (2018). Pengaruh Jus Buah Durian Mentega ( Durio zibethinus Murr.) Terhadap Profil Farmakokinetik Parasetamol pada Kelinci Jantan. Jurnal Kesehatan.

Efendi, E., Fuad, A. P., Mudzakir, T., Kiky, M. A., Ain, Y., Insani, dan B. G. A (2016). Efek nefroprotektif ekstrak bawang kucai (allium tuberosum) terhadap kadar blood urea nitrogen (bun) dan kreatinin tikus wistar yang diinduksi doxorubicin. Nurseline Journal. Vol 1. No. 2: 203-211.

F. Paulsen dan J.Waschke. Sobotta, Atlas Anatomi Manusia Ed. 23. Jakarta Ganong, W.F., (2010). Pathophysiology of Disease: An Introduction to Clinical Medicine, 5th Ed.,diterjemahkan oleh Brahm, U., hal 493-500, EGC, Jakarta.

Goodman, A., dan Gilman, H. (2014). Dasar Farmakologi Terapi Ed. 10 Vol. 2 Jakarta.EGC.

Harmita, Radji. (2010). Buku ajar Analisis Hayati. Jakarta. EGC.

Herman, H., Sitti, A., dan Triani, P. A. Efek hepatoprotektor ekstrak etanol rimpang dringo (Acorus calamus L.) terhadap peningkatan kadar SGPT tikus putih (Rattus norvegicus). As-Syifaa. Vol. 10(1): 92-98.

Hidayat, S., Napitupulu, R.M. (2015). Kitab Tumbuhan Obat. Jakarta: AgriFlo (Penebar Swadaya Grup). 265.

Irianto, K.( 2013). Anatomi dan Fisiologi Untuk Mahasiswa. Penerbit Alfabeta. Bandung.

Jozwiak-Bebenista, M. and Nowak, J. Z. (2014) 'Paracetamol: Mechanism of action, applications and safety concern', Acta Poloniae Pharmaceutica - Drug Research, 71(1). 11-23.

Kalender, Y., Yel, M., and Kalender, S. (2005). Doxorubicin hepatotoxicity and hepatic free radical metabolism in rats. The effects of vitamin $E$ and Ndruru, M. F., dan Edward, K. (2019). Uji efektivitas ekstrak daun benalu jeruk (Dendrophthoe glabrescens) sebagai nefroprotektor terhadap kerusakan ginjal yang di induksi dengan paracetamol pada tikus putih (Rattus novergicus). Jurnal Biosains. Vol. 5 No. 2. $45-52$.

Maswita. (2020). The Role of Health Promotion on Smoke Free Area Implementation at Regional Work Unit Langsa City. ritain International of Exact Sciences (BIoEx) Journal.p. 298-303.

Sarpini, R. (2014). Anatomi dan Fisiologi Tubuh Manusia Untuk Paramedis.Bogor:Penerbit IN MEDIA.

Setiati S, Alwi I, Sudoyo AW, Stiyohadi B, Syam AF. Buku ajar ilmu penyakit dalam jilid I. VI. Jakarta: InternaPublishing; 2014.

Sherwood, lauralee (2014) Fisiologi Manusia. 8th edn. Jakarta: EGC Medical Publisher.

Snell, Richard S. (2014). Anatomi Klinis. Jakarta. EGC. 